\title{
The Influence of Taxpayers' Awareness and Compliance in Generating Local Revenue Moderated by the Government: A Case Study on the Government of Regional Mandailing Natal
}

\author{
Azizul Kholis ${ }^{1, *}$, Sutrisno ${ }^{1}$, Renny Maisyarah ${ }^{2}$ \\ ${ }^{1}$ Universitas Negeri Medan \\ ${ }^{2}$ Universitas Pembangunan Panca Budi \\ "Corresponding author.Email: azizulkholis@unimed.ac.id
}

\begin{abstract}
This study aims to determine the influence of taxpayers' awareness and compliance in generating local revenue moderated by the government. Data were collected from 64 Mandailing Natal Regency taxpayers from hotels, restaurants, and bird nest businesses using cluster sampling. The obtained data were analyzed using multiple regression analysis techniques with the help of the SPSS program. The result showed that the taxpayers' awareness and compliance moderated by tax governance simultaneously affect the locally-generated revenue. It also showed that taxpayers' awareness does not affect locally-generated revenue, as opposed to their compliance, which has a significant and positive effect. Similarly, their awareness moderated by tax governance has a positive effect on locally-generated revenues, as opposed to their compliance.
\end{abstract}

Keywords: Taxpayer Awareness, Taxpayer Compliance, Tax Management, And Locally-Generated Revenue

\section{INTRODUCTION}

Locally-generated revenue is defined as the revenue collected by the authority of an area, based on local regulations and applicable laws. According to Mayza [16], locally-generated revenue are sourced from local taxes, regional levies, the profits of regionally owned companies, and the results of the management of separated regional assets, etc. This type of revenue is directly managed by the local government to meet the region's financing and developmental needs. However, most regional governments do not optimally utilize the sources of the regional revenue, thereby leading to its inability to achieve set targets. This is evidenced by the state of excavation $\mathrm{C}$, where many $\mathrm{C}$ mining and wallet bird nest companies do not have operational licenses due to the difficulty obtaining permits. In addition, the majority of people in Mandailing Natal Regency do not possess an adequate understanding of the system of selfassessment methods that applies.

According to [4], a self-assessment system is a collection that provides taxpayers the authority to calculate, deposit, and report the amount of tax owed.
The self-assessment system works when people have high knowledge, good tax morals, and high tax discipline, including the taxpayer's trust in the country. This system allows prospective taxpayers not to carry out their tax obligations properly, thereby overcoming the act of negligence, gaps, or ignoring their responsibilities. The implementation of this system requires the public to possess adequate knowledge of the tax calculation provisions and applicable regulations [13]. Furthermore, [17] stated that the implementation tends to be effective with the establishment of voluntary compliance conditions. Taxpayers are required to be active starting from the moment they register, to filling out the SPT (Notification Letter) with honesty, down to paying the tax promptly.

According to [26], taxpayer compliance affects the self-assessment system in payments. Therefore, it needs to be a spotlight for the government and society. Internal and external factors influence this system. Internal factors originate from the taxpayer, and it is related to individual characteristics that are triggered when carrying out tax-related obligations. The internal factors that influence taxpayer compliance are education, 
diversity, tax awareness, understanding tax laws, and regulations, and rational factors. In contrast to internal factors, the external originate from outside the Taxpayer themselves, from their surrounding environment. A good tax authority's service is expected to be able to improve compliance, as regulated through the Directorate General of Tax Circular No. SE-84 / PJ / 2011 concerning excellent service. Therefore, to increase taxpayer compliance in fulfilling their obligations, tax officials' quality of services needs to be improved, which includes increasing public knowledge on tax.

Taxpayer awareness is the condition of knowing or understanding tax payment policies to improve compliance. The government's positive assessment of the implementation of state functions tends to motivate the public to comply with their tax payment obligations. Therefore, it is necessary to ensure that the taxpayers are aware of the rules to improve their compliance. In reforming alternative policies, it is necessary to grant flexibility to local governments for regional development. According to the regulations associated with the region's administration through Law No. 32 of 2004 concerning regional government and Law No. 33 of 2004 on the financial balance between the central and regional governments.

Based on this law, regions are given the authority to collect 11 types of taxes and 28 types of user fees. Therefore, judging from the contribution of regional taxes and levies there has been a relatively large imbalance in the distribution of taxation authority between the center and the regions. This is reflected in the amount of tax that does not have a major impact on increasing locally-generated revenue because financing needs in most regions has a PAD of less than $10 \%$, which significantly varies in each region between $10 \%-50 \%$ because regional taxing power is very limited and tends to lead to low regional financial capacity ultimately

The issuance of Law No. 28 of 2009 concerning local taxes and regional levies has expanded the tax object that can be taken into consideration in calculating its future potential. Based on Law No. 28 of 2009, Regency tax types consist of Hotel Tax, Restaurant Tax, Entertainment Tax, Advertisement Tax, Street Lighting Tax, Non-metallic Mineral, and Rock Tax, Parking Tax, Groundwater Tax, Swallow Bird Nest Tax, Land and Building Tax, and Fees for Obtaining Rights of Land and Buildings (BPHTB). In the next five years, challenges that need to be overcome include the need for accelerated regional economic development to grow tax potential, intensification of regional tax collection and structuring, revamping tax administration, improving tax service, and socialization counselling to increase public participation in paying taxes. The regional regulations related to the potential of the Mandailing Natal Regency include Number 14 of 2012 Regarding Management of Building Permits (IMB), Number 9 of 2011 concerning Business
Service Levies, Number 10 the Year 2011 Regarding Certain Licensing Levies, Number 8 of 2011 concerning General Service Levies, Number 7 of 2011 Regarding Local Taxes. Several studies have been carried out related to the original revenue of the region including studies carried out by [15] in Zimbawe, Kundalini [11] in Indonesia, [17], and [24] in Malaysia.

Tax non-compliance is a lack of awareness by taxpayers, followed by the inability to pay, the use of poor and inadequate collection system, and expectations of forgiveness in terms of tax penalties [1]. Personal tax knowledge and compliance behavior face different business conditions among large companies and MSME, making them bear the burden of high tax compliance [15].

According to [11], those with regard to their tax obligations and awareness tend to affect Indonesia's taxation system. Awareness of paying taxes plays an important role in fostering compliant behavior. The unconsciousness of taxpayers can lead to a deliberate act to avoid payment, which tends to harm the country ultimately [7].

In practicing corporate governance, relevant information needs to be published on their tax planning practices to demonstrate moral awareness, with selfexplanatory information [9]. The study from [24] reported that the quality of service, sanctions, regulations, and fines encourage taxpayer awareness and compliance. This study is a replication of the research carried out by [1], [15], and [11]. However, the difference between this research and [1] is the addition of a dependent variable, such as locally-generated revenue known as compliance. This study failed to use the compliance variable because the local revenue is an indicator of the independence of regional autonomy consisting of tax revenues, user fees, and other sources. Tax revenues are only part of several regional revenue sources. The level of local tax revenue is assessed from the compliance of taxpayers in paying taxes. Therefore, this study uses taxpayer compliance as an independent variable to determine the compliance effect on local tax revenue or regional original income.

The differences between this study and Maseko [15] are variable awareness of taxpayers. In Maseko's research, there is no taxpayer awareness variable, however, this study used it due to the low level of tax revenue owing to lack of public knowledge, education, and government socialization.

The object in this study is direct taxpayers, while the [11] research uses the Pratama Tax Service Office as the research object. This study used taxpayers as the object of research due to the awareness and obedience of oneself by taxpayers.

From the above background, several problems arise in paying local taxes as follows: 
1) Does awareness of taxpayers affect local revenue?

2) Does taxpayer compliance affect local revenue?

3) Does awareness of taxpayers affect local revenue that is moderated by tax governance?

4) Does taxpayer compliance affect local revenue that is moderated by tax governance?

Theoretically, this research is expected to add insight into science in the field of taxation, especially the issue of awareness of prospective taxpayers in fulfilling their obligations and knowing the tax benefits paid.

\section{THEORETICAL FRAMEWORK}

\subsection{Taxation Obligations}

According to [20], tax compliance is defined as a situation where taxpayers fulfil all tax obligations. The [2] define tax compliance as the willingness of people, companies, and other taxable foundations to comply with tax laws in letter and spirit and comply with tax administration requirements without using forced tools.

According to [27], the factors that influence taxpayer compliance is as follows:

\section{a. Effect of Morality}

Motivation arises in taxpayers' willingness to contribute to the state by paying taxes. Morality is an aspect of tax compliance with demographic, national pride, citizen participation, trust, regional autonomy, economic conditions, and taxation system as some of the underlying factors.

b. Cultural influences

This is the overall formal and informal interaction in an institution that connects the national taxation system with taxpayers that have historically been attached to the national culture. This includes the dependencies and bonds that are formed as a result of continuous interaction.

c. Influence of Religion

Indonesia has a variety of beliefs, with differences in beliefs capable of dividing people. Therefore religion influences tax collection due to the tolerance between religious communities.

d. Effects of Education

According to [21] the factors that influence the level of compliance are the amount of costs that need to be incurred by taxpayers, as well as the time spent in fulfilling their obligations, starting from the time of reading the tax return form and the instruction manual, to consulting with an accountant or consultant to fill in the tax return form, as well as the time taken to commute to the tax office.
The higher a person's education, the higher their awareness of paying taxes for the community's development and welfare.

\subsection{Tax Awareness}

According to Hastuti [1-], taxpayer awareness is the self-awareness of individuals responsible for calculating, paying, and reporting their own taxes. [21] stated, defined it as a taxpayers' willingness to pay tax obligations without being mandated. Those that are aware of their taxes are likely not to violate the existing regulations, with the ability to calculate their taxes correctly and make payment in due time. Taxpayer awareness is their behavior in the form of views or perceptions that involve beliefs, knowledge and reasoning, and their tendency to act according to the stimulus provided by the applicable system [11]

From the above understanding, it can be concluded that the awareness of taxpayers is a situation where they have adequate ideas on tax-related issues. Taxpayer awareness is needed, assuming the person involved is aware of rules, in compliance with the tax payments, thereby, reducing the increasing rate of reluctance.

\subsection{Locally-generated revenue}

Locally-generated revenue is the income derived from local tax revenue, regional levies, and other legitimate [18] needed for the implementation of development activities by the government. Locallygenerated revenue is an indicator of the independence of regional autonomy in exploring potentials to increase revenue [23]. The greater the $\mathrm{PAD}$, the more independent the region is in making development decisions and policies.

\subsection{Good Governance (Good Governance)}

According to the United Nations Development Program (UNDP) in its policy document entitled "Governance for sustainable human development" (1997), good governance is a synergistic and constructive relationship between countries, the private sector, and societies [5].

According to o [14], good governance is the concept and approach oriented to the development of the public sector. [8] defined it as a mechanism for managing economic and social resources that involve the state and non-state sectors' influence in a collective effort.

Therefore, it can be concluded that good governance is more focused on the growth of a synergistic public sector to manage the resources of a country effectively and efficiently for the benefit of society in line with applicable laws and regulations and avoiding selfinterests such as corruption, collusion and nepotism. 


\subsection{Hypothesis Development}

\subsubsection{Effect of awareness of taxpayers on local income}

There is limited awareness regarding the ability of taxpayers to pay taxes and report local tax returns. [11] stated that those that careless about their tax obligations and awareness tend to affect how taxation is carried out in Indonesia. The perception that taxpayers have on taxes and the benefits to be received is associated with their knowledge of the procedures and applicable conditions such as their characteristics, economic factors, and public outreach. It is concluded that the awareness of taxpayers tends to affect local own-source revenue.

H1: The effect of awareness of taxpayers has a positive effect on local own-source revenue

\subsubsection{The effect of taxpayer compliance on original regional income}

Compliance to pay taxes affects the local revenue due to their attitude to carry out their obligations both from internal and external factors. According to [6], compliance arises due to various factors such as education and knowledge on tax, taxation systems, information and counseling on tax, geographic location, performance apparatus, law enforcement, and services provided by the government to taxpayers.

Knowledge of taxation accompanied by higher education and law enforcement that consistently make taxpayer compliance in paying taxes tend to affect the region's original income.

$\mathrm{H} 2$ : The effect of taxpayer compliance has a positive impact on local own-source revenue

\subsubsection{Effect of taxpayer's awareness on local revenue moderated by tax governance}

According to [3], tax governance affects local revenue in accordance with the acceptance of Regional Taxes and Retribution, which has a close interest in the services provided by local governments to the community. The lack of optimal local revenue in contributing to the sources also indicates poor tax management, with separated regional assets. This problem shows that tax governance affects local real income.

H3: The effect taxpayer awareness has a positive effect on local revenue moderated by tax governance

\subsubsection{The effect of taxpayer compliance on regional revenue moderated by governance}

Taxpayers' awareness to pay taxes affects the region's original income, due to the lack of public awareness and application of weak regulations. Therefore, in increasing local revenue, the government needs to provide maximum services by improving tax governance and applying sanctions.

H4: Taxpayer compliance has a positive effect on local government revenue moderated by governance

From the description above, this research framework can be described as follows:

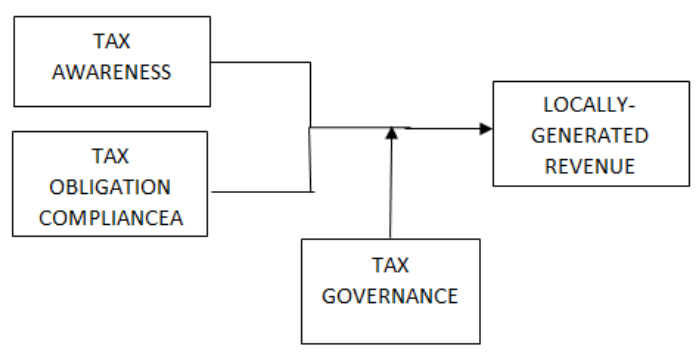

Figure 1. A research framework

\section{METHODS}

This research was carried out in the Mandailing Natal Regency Government, from June to July 2019. The population consists of objects or subjects with certain qualities and characteristics in accordance with the studies with conclusions drawn. [25] stated that samples are used to determine the characteristics possessed by the population. Data were collected from 64 Mandailing Natal Regency taxpayers from hotels, restaurants, and bird nest businesses using the cluster sampling technique.

Primary data were obtained from respondents' answers to a closed questionnaire posed in writing.

This study uses multiple regression data analysis to test for the hypothesis. Analysis of multiple regression data is a linear relationship between several independent variables such as $\mathrm{X} 1, \mathrm{X} 2$, and $\mathrm{X}$, with the dependent variable (Y). This analysis is to determine the relationships whether each independent variable is positively or negatively related to the dependent with an increase or decrease in value.

This study also examines the effect of taxpayer awareness (X1) and Taxpayer Compliance (X2) on Locally-generated revenue (Y) which is moderated by Tax Management (X3), using the following regression equation:

$$
\begin{aligned}
& Y=a+b 1 X 1+b 2 X 2+b 3 X 3+e \\
& X 3=a+b 1 X 1+b 2 X 2|e|
\end{aligned}
$$




\section{RESULTS AND DISCUSSION}

\subsection{Simultaneous Test}

Simultaneous test (Test F) is used to determine whether all independent variables included in the model have a shared influence on the dependent variable. Simultaneous test results (Test F) in this study are shown in Table 1.

Table 1. The Result of F-Test

ANOVA ${ }^{\mathrm{a}}$

\begin{tabular}{|c|c|c|c|c|c|c|}
\hline & Model & Sum of Squares & df & Mean Square & $\mathrm{F}$ & Sig. \\
\hline \multirow{3}{*}{1} & Regression & .073 & 3 & \multirow{3}{*}{$\begin{array}{l}.024 \\
.001\end{array}$} & \multirow[t]{3}{*}{23.112} & \multirow[t]{3}{*}{$.000^{\mathrm{b}}$} \\
\hline & Residual & .063 & 60 & & & \\
\hline & Total & .136 & 63 & & & \\
\hline
\end{tabular}

Table 1 shows that the calculated $F$ value is 23,112 and sig $0,000 \mathrm{~b}$. Because of the calculated $\mathrm{F}$ value of $23.112<$ F table 2.76, Sig 0.000b $>0.05$, it can be concluded that taxpayers' awareness and compliance are simultaneously moderated by governance with a significant effect on original local income.

\subsection{Partial Test (t-Test)}

The t-test statistic is used to determine the influence of an independent variable in explaining the variation of the dependent. The criteria used in making decisions are assuming $\mathrm{t}$-arithmetic $>\mathrm{t}$-table at $\mathrm{a}=5 \%$ and the probability value <level at the significance of 0.05 , then the independent variable influences the dependent. However, assuming the $\mathrm{t}$-arithmetic $<\mathrm{t}$-table at $\mathrm{a}=5 \%$ and the probability value $>$ level of significance is 0.05 , the independent variable does not affect the dependent. Table 2 shows the results of the partial t-test.

Table 2. The Results of The Partial t-Test

\begin{tabular}{|c|c|c|c|c|c|c|}
\hline \multicolumn{7}{|c|}{ Coefficients } \\
\hline & \multirow[t]{2}{*}{ Model } & \multicolumn{2}{|c|}{$\begin{array}{l}\text { Unstandardized } \\
\text { Coefficients }\end{array}$} & $\begin{array}{l}\text { Standardized } \\
\text { Coefficients } \\
\end{array}$ & \multirow[t]{2}{*}{$\mathrm{t}$} & \multirow[t]{2}{*}{ Sig. } \\
\hline & & B & Std. Error & Beta & & \\
\hline \multirow{4}{*}{1} & (Constant) & ,073 & ,196 & & ,374 & ,709 \\
\hline & Tax Awareness &,- 117 & ,088 &,- 135 & $-1,332$ & , 188 \\
\hline & Tax Governance & ,397 & ,205 & ,335 & 1,937 & 057 \\
\hline & $\begin{array}{l}\text { Tax Awareness x Tax } \\
\text { Governance }\end{array}$ & ,329 & , 119 & ,483 & 2,775 & ,007 \\
\hline
\end{tabular}

\subsubsection{Taxpayer Awareness (X1) of Local Revenue $(Y)$}

The t-value calculated from taxpayer awareness is 1.332 , and Sig value is 0.188 . Therefore, it can be interpreted that the value of $t$-arithmetic $(1,332)$ is below t-table $(2,00030)$ and Sig 0.188>0.05, then the awareness of taxpayers does not affect the original income. Therefore, $\mathrm{H} 1$ is rejected.

\subsubsection{Taxpayer awareness moderated by tax governance (X1.Z) towards local own- source revenue $(Y)$}

The t-value of the independent board of commissioners is 2.775 , and the sig is 0.007 . Therefore, it can be interpreted that the value of t-arithmetic (2.775) is above t-table $(2,000030)$ and Sig 0.007 above 0.05 . This means that the taxpayers' moderated awareness has a significant effect on regional original income. Therefore, H3 is accepted. 
Table 3. Partial Test Results (T-Test) Taxpayer Compliance with Moderating Variables.

\section{Coefficients $^{\mathbf{a}}$}

\begin{tabular}{|c|c|c|c|c|c|c|}
\hline \multirow{2}{*}{\multicolumn{2}{|c|}{ Model }} & \multicolumn{2}{|c|}{$\begin{array}{l}\text { Unstandardized } \\
\text { Coefficients }\end{array}$} & $\begin{array}{c}\text { Standardized } \\
\text { Coefficients }\end{array}$ & \multirow[t]{2}{*}{$\mathrm{t}$} & \multirow[t]{2}{*}{ Sig. } \\
\hline & & B & Std. Error & Beta & & \\
\hline \multirow{4}{*}{1} & (Constant) & ,073 & ,196 & & ,374 & ,709 \\
\hline & Tax Awareness & ,329 & , 119 & ,283 & 2,775 & ,007 \\
\hline & Tax Governance & ,843 &, 180 & ,712 & 4,682 & ,000 \\
\hline & $\begin{array}{l}\text { Tax Awareness x Tax } \\
\text { Governance }\end{array}$ &,- 117 & ,088 &,- 202 & $-1,332$ &, 188 \\
\hline
\end{tabular}

\subsubsection{Taxpayer Compliance (X2) Against Local Revenue $(Y)$}

The t-value of taxpayer compliance is 2.775 at a Sig of 0.007 . This means $|2.775|>t$ table $|2,00030|$ and Sig $0.007<0.05$, This means that the taxpayer compliance has a significant effect on regional original income. Therefore, $\mathrm{H} 2$ is accepted.

\subsubsection{Compliance of taxpayers that are} moderated by tax governance (X2.Z) to local own-source revenue $(Y)$

The t-value calculated from tax compliance, which is moderated by tax governance, is 1.332 with a Sig of 0.188 . It can be interpreted that the value of t-arithmetic | $1,332 \mid<$ t table | $2.000030 \mid$ and Sig 0.188 above 0.05 . This means that the compliance of the moderated taxpayers does not affect the original regional income. Therefore, $\mathrm{H} 4$ is rejected.

\section{CONCLUSIONS}

The research and discussion results of this study led to the following conclusions:

a. Taxpayers' awareness does not influence locallygenerated revenue due to their inadequate knowledge of tax.

b. Taxpayers' compliance has a positive effect on local revenue due to the excellent service provided by the local tax service and the establishment of education for adequate understanding and knowledge of tax.

c. Taxpayers moderated by governance affects the local revenue, due to the counselling and socialization carried out on tax.

Furthermore, their compliance does not affect the local revenue because there are fines imposed on taxpayers as sanctions for late payment.

\section{REFERENCES}

[1] Adimasu, N. A., Tax Awareness and Perception Of Tax Payers And Their Voluntary Tax Complience Decision: Evidence From Individual Tax Payers In Snnpr, Ethiopia. International Journal of Scientific and Research Publications, 2017, pp 686-695.

[2] Al-Maghrebi, M. S., Ahmad, R., \& Palil, M. R., Budget Transparency and Tax Awareness Towards Tax Compliance: A Conseptual Approach. South East Asia Journal of Contemporary Business, Economics and Law, 2016, pp 95-105.

[3] Andriani, N., Eksistensi Pengaturan Pajak Daerah Dalam Meningkatkan Pendapatan Asli Daerah Di Pemerintah Provinsi Jawa Tengah. Jurnal Hukum Khaira Ummah, 2017, 59-66.

[4] Anitasari, A. M., Analisis Penerapan SelfAssessment System Pajak Hiburan Di Kota Blitar. Jurnal Perpajakan (Jejak), 2016, pp 1-11.

[5] Dwiyanto. Mewujudkan Good Governance Melalui Pelayanan Publik. Yogyakarta: Gadjah Mada University Press, 2005.

[6] Faizah, S., Faktor Faktor Yang Mempengaruhi Kepatuhan Wajib Pajak Dalam Membayar Pajak Bumi Dan Bangunan (Studi Kasus Di Kecamatan Dukuhturi Kabupaten Tegal). Skripsi. Fakultas Ekonomi, Universitas Negeri Semarang. 2009.

[7] Fuadi, A. O., Pengaruh Kualitas Pelayanan Petugas Pajak, Sanksi Perpajakan Dan Biaya Kepatuhan Pajak Terhadap Kepatuhan Wajib Pajak Umkm. Tax \& Accounting Review. 2013.

[8] Ganie, R., Good Governance, Prinsip, Komponen, Dan Penerapannya Dalam Hak Asasi Manusia (Penyelenggara Negara Yang Baik). Jakarta: Penerbit Komnas Ham. 2000.

[9] Gribnau, H. J., Good Tax Governance: A Matter of Moral Responsibility and Transparency. Nordic Tax Journal. 2017. 
[10] Hastuti, R., Tax Awareness and Tax Education: A Perception of Potential Taxpayers. International Journal of Business, Economics and Law. 2014.

[11] Kundalini, P., Pengaruh Kesadaran Wajib Pajak Dan Pelayanan Pegawai Pajak Terhadap Kepatuhan Wajib Pajak Pada Kantor Pelayanan Pajak Pratama Kabupaten Temanggung Tahun 2015. Universitas Negeri Yogyakarta. 2016.

[12] Kusuma, I. B., Pengaruh Kesadaran, Kualitas Pelayanan, Sanksi Dan Pemahaman Peraturan Perpajakan Pada Kepatuhan Wajib Pajak Hotel. EJurnal Akuntansi Universitas Udayana, 2016, pp 565-590.

[13] Lasmaya, S., Pengaruh Self Assesment System Terhadap Kepatuhan Wajib Pajak. Jurnal Computech \& Bisnis,, 2017, pp 69-78.

[14] Mardiasmo. Perpajakan Edisi Revisi. Yogyakarta: Andi. 2013.

[15] Maseko, N., Determinants of Tax Compliance by Small and Medium Enterprises in Zimbabwe. Journal of Economics and International Business Research, 2014, pp 48-57.

[16] Mayza, M., Analisis Faktor-Faktor Yang Mempengaruhi Pendapatan Asli. Jurnal Ilmu Ekonomi Pascasarjana Universitas Syiah Kuala, 2015, pp 9-16.

[17] Nalendro, T. I., Faktor-Faktor Yang Mempengaruhi Kepatuhan Membayar Pajak Wajib Pajak Orang Pribadi Yang Berwirausaha Dengan Lingkungan Sebagai Variabel Moderasi (Studi Empiris Di Kpp Pratama Kudus). Diponegoro Journal of Accounting, 2014, pp 1-15.

[18] Nurcholis, H., Teori Dan Praktek Pemerintahan Dan Otonomi Daerah. Jakarta: Pt Gramedia Widiasarana Indonesia. 2007.

[19] Palil. The Perception of Tax Payers on Tax Knowledge and Tax Education with Level of Tax Compliance: A Study the Influences Of Religiosity. Asean Journal of Economics, Management and Accounting. South East Asia Journal of Contemporary Business, Economics and Law, 2016, pp 118-129.

[20] Rahayu, S. K. Perpajakan Indonesia: Konsep Dan Aspek Formal. Yogyakarta: Garaha Ilmu. 2013.

[21] Rahman, A., Administrasi Perpajakan. Bandung: Nuansa. 2010.

[22] Sanders, D., Influence of Accountability and Penalty Awareness on Tax Compliance. Journal of The American Taxation Association. 2008.
[23] Sari, P. L., Analisis Variabel-Variabel Yang Mempengaruhi Pendapatan Asli Daerah (Pad) Provinsi Bali. Jurnal Ilmiah Akuntansi Dan Humanika, 2013, pp 715-737.

[24] Savitri, E., The Effect of Tax Payers Awareness, Tax Sosialization, Tax Penalties, Compliance Cost at Taxpayers Compliance with Service Quality as Mediating Variable. Social and Behavior Science, 2016, pp 682-687.

[25] Sugiyono. Metode Penelitian Bisnis. Bandung: Alfabeta. 2012.

[26] Tuwo, V., Pengaruh Sikap Dan Kesadaran Wajib Pajak Terhadap Kepatuhan Wajib Pajak Bumi Dan Bangunan Di Kelurahan Tara-Tara Kota Tomohon. Jurnal Emba,2016, pp 087-097.

[27] Widodo, W., Moralitas, Budaya, Dan Kepatuhan Pajak. Bandung: Alfabeta. 2010. 